\title{
A Review of Neuromodulation in the Neurorehabilitation
}

\author{
Dali Yin and Konstantin V Slavin* \\ Department of Neurosurgery, University of Illinois at Chicago, Chicago, IL, USA
}

\begin{abstract}
For many years, invasive neuromodulation has been used in neurorehabilitation, mainly in treatment of movement disorders and various psychiatric conditions. Use of deep brain stimulation and other implanted electrical stimulators is being explored in other conditions, such as stroke, traumatic brain injury and spinal cord injury. This paper provides a review of the possible role of Neuromodulation in neurorehabilitation and highlights some of its applications for patients with various neurological conditions. Since most of the existing findings are based on animal studies, preliminary data, case reports and poor-controlled studies, further investigations including research and clinical trials are necessary to increase the applications of neurostimulation in the field of neurorehabilitation.
\end{abstract}

Keywords: Neuromodulation; Neurorehabilitation; Stroke; Traumatic brain injury; Spinal cord injury; Epilepsy

\section{Introduction}

Neurorehabilitation is a complicated medical process; its goal is to help patients to recover from injuries or abnormalities in the Central Nervous System [CNS], and to compensate for functional deficits if possible. Neurorehabilitation offers a series of therapies, including physical, occupational, speech, psychological therapies and so on with a focus on improving the patients' health. The field of neurorehabilitation is relatively new, and some cutting edge therapies, including neuromodulation, that may be potentially beneficial topatients withCNS injuries or other disorders, are currently being investigated. The brain operates through signal processing within neural networks $[1,2]$. The advances in the understanding of brain circuitry, together with the development of neurostimulation technologies have prompted us to explore the potential of electrical stimulation of the nervous system to promote functional recovery in patients with CNS disorders through activation of neuronal structures and alteration or inhibition of pathological pattern of neuronal activity. Over the past several decades, electrical neurostimulation of deep cerebral structures hasbeen proven a clinically effective therapy in the treatment of movement disorders with a remarkable safety profile $[3,4]$. Neurostimulation approach in patients with movement disorders has shed light on the possibility of correcting abnormal networks. The neurostimulation technology has been also applied to psychiatric disorders and chronic pain. The objective of this review is to explore the use of neurostimulation in treatment of stroke, traumatic brain injury, spinal cord injury and epilepsy. A thorough search of the literature was conducted in preparation of this review.

\section{Neuromodulation for Brain Injury Caused By Stroke And Trauma}

The incidence rate of Traumatic Brain Injury [TBI] is 558 per 100,000 people [5], and that of stroke is $67-70$ per 100,000 [6]. Brain injury caused bytrauma and stroke remains a significant public health problem with devastating consequences, and is a leading cause of disability and death in the world. New therapeutic strategies are needed for treatment of neurological functional deficits followingtraumatic or ischemic brain injury. Neuromodulation approach has been employed to treat stroke and TBI in animal models [7-11] and clinical studies [12-14], with preliminary data showing that neurostimulation may lead to functional improvement in the setting of brain injuries. A few animal studies in non-human primates have observed thatcortical stimulationenhances functional recovery and cortical plasticity after neural injury induced by stroke [7-9]. Cortical stimulation during rehabilitation constantly improves motor function in ratsfollowing motor cortex injury [10-11].

\section{Motor Cortex Stimulation}

A small randomized clinical trial $[\mathrm{n}=24]$ found that Motor Cortex Stimulation [MCS] lead to motor and functional improvements [difference of Fugl-Meyer motor scores in estimated means $=3.8, \mathrm{p}=$ $.042]$ in stroke patients, and the effect was maintained during 6 -month follow-up period [12]. In a multicenter safety and efficacy study, MCSresulted in improvementsin upper-extremity function during 3 weeks or 6 weeks $[13,14]$ of the rehabilitation. MCS for 3 weeks during stroke rehabilitation also led to improvement inpincer movement of the previously paretic hand in a hemi-paretic stroke patient [13]. Moreover, MCS resulted in $40 \%-50 \%$ improvement of pain caused by brain injury in approximately $50 \%$ of patients [15]. Table 1 shows clinical data of different studies. However, the limitations of these studies on MCS include small sample size and short follow up. Overall, the long-term effect of MCS is uncertain, as no study has explored that.The mechanismsby which such improvements occur are not clear.The improvements may be a result of increased dendritic plasticity and decreased astrogliosis in the perilesional cortex and the contralesional anterior horn of the cervical spinal cord as shown by an immunohistochemical study[16]. Another study indicated motor cortex stimulation after pyramidotomy could increase the length of axons from theprimary motor cortex to the spinal cord, as well as to the red nucleus and cuneate nucleus [17]. Increased axonal outgrowthwith stimulation may be due to a release of neurotrophins, such as brain-derived neurotrophic factor, and increased motor activityof the subjects [7].

\section{Deep Brain Stimulation}

DBS has been explored on patients with Persistent Vegetative State [PVS] or minimally conscious state [MinCS] following traumatic brain injury.In the late 1960-s, Hassler et al described the concept of using

*Corresponding author: Konstantin V Slavin, Department of Neurosurgery, University of Illinois at Chicago, 912 South Wood Street, M/C 799, Rm. 451N, Chicago, IL 60612,Tel: 312-996-4842; Fax: 312-996-9018; E-mail: kslavin@uic.edu

Received December 09, 2014; Accepted February 28, 2015; Published March 06,2015

Citation: Yin D, Slavin KV (2015) A Review of Neuromodulation in the Neurorehabilitation. Int $\mathrm{J}$ Neurorehabilitation 2: 151. doi:10.4172/23760281.1000151

Copyright: (c) 2015 Yin D, et al. This is an open-access article distributed under the terms of the Creative Commons Attribution License, which permits unrestricted use, distribution, and reproduction in any medium, provided the original author and source are credited. 
Citation: Yin D, Slavin KV (2015) A Review of Neuromodulation in the Neurorehabilitation. Int J Neurorehabilitation 2: 151. doi:10.4172/23760281.1000151

Page 2 of 5

\begin{tabular}{|c|c|c|c|c|c|c|c|c|c|}
\hline \multicolumn{2}{|c|}{$\begin{array}{l}\text { Clinical data of different } \\
\text { studies }\end{array}$} & \multirow[b]{2}{*}{ Ref \# } & \multirow[b]{2}{*}{$\begin{array}{l}\text { Types of } \\
\text { Study }\end{array}$} & \multirow[b]{2}{*}{$\begin{array}{l}\text { Sample } \\
\text { Size }\end{array}$} & \multirow[b]{2}{*}{$\begin{array}{c}\text { Study } \\
\text { Population }\end{array}$} & \multirow[b]{2}{*}{ Groups } & \multirow[b]{2}{*}{ Outcome Measures } & \multirow[b]{2}{*}{$\begin{array}{l}\text { Results and } \\
\text { Outcome Data }\end{array}$} & \multirow[b]{2}{*}{ Follow up } \\
\hline $\begin{array}{c}\text { Type of } \\
\text { Neurostimulation }\end{array}$ & Authors & & & & & & & & \\
\hline $\begin{array}{l}\text { Mortor Cortex } \\
\text { Stimulation }\end{array}$ & $\begin{array}{l}\text { Huang } \\
\text { et al }\end{array}$ & 12 & $\begin{array}{l}\text { Small phase } \\
\text { II pilot study }\end{array}$ & 24 & $\begin{array}{c}\text { Ischemic } \\
\text { stroke patients }\end{array}$ & $\begin{array}{l}\text { Stimulation with } \\
\text { rehabilatation vs } \\
\text { rehabilation alone }\end{array}$ & $\begin{array}{l}\text { Upper extremity Fugl- } \\
\text { Meyer score }\end{array}$ & $\begin{array}{c}\text { Improvement in } \\
\text { upper extremity } \\
\text { motor control in the } \\
\text { investigational group }\end{array}$ & 6 months \\
\hline $\begin{array}{l}\text { Mortor Cortex } \\
\text { Stimulation }\end{array}$ & Brown et al & 13 & $\begin{array}{l}\text { Nonblinded } \\
\text { trial and } \\
\text { safety study }\end{array}$ & 10 & $\begin{array}{c}\text { Ischemic } \\
\text { stroke patients }\end{array}$ & $\begin{array}{l}\text { Stimulation with } \\
\text { rehabilatation vs } \\
\text { rehabilation alone }\end{array}$ & $\begin{array}{l}\text { Upper extremity Fugl- } \\
\text { Meyer score }\end{array}$ & $\begin{array}{l}\text { signoficant } \\
\text { improvement in } \\
\text { upper extremity } \\
\text { motor control in } \\
\text { stimulation plus } \\
\text { rehabilitation }\end{array}$ & 12 weeks \\
\hline $\begin{array}{l}\text { Mortor Cortex } \\
\text { Stimulation }\end{array}$ & Levy et al & 14 & $\begin{array}{l}\text { Safety and } \\
\text { efficacy } \\
\text { study }\end{array}$ & 24 & $\begin{array}{c}\text { Ischemic } \\
\text { stroke patients }\end{array}$ & $\begin{array}{l}\text { Stimulation with } \\
\text { rehabilatation vs } \\
\text { rehabilation alone }\end{array}$ & $\begin{array}{l}\text { Upper extremity Fugl- } \\
\text { Meyer score, Arm motor } \\
\text { ability test }\end{array}$ & $\begin{array}{l}67 \%, \text { Improvement } \\
\text { in upper extremity } \\
\text { motor control. }\end{array}$ & 4 weeks \\
\hline $\begin{array}{l}\text { Deep Brain } \\
\text { Stimulation }\end{array}$ & $\begin{array}{l}\text { Hassler } \\
\text { et al }\end{array}$ & 18 & Case report & 1 & $\begin{array}{l}\text { Post-traumatic } \\
\text { apallic } \\
\text { syndrome }\end{array}$ & $\mathrm{N} / \mathrm{A}$ & $\begin{array}{l}\text { Behavioural and EEG } \\
\text { measurement }\end{array}$ & $\begin{array}{l}\text { Behavioural and } \\
\text { EEG arousal. }\end{array}$ & $\mathrm{N} / \mathrm{A}$ \\
\hline $\begin{array}{l}\text { Deep Brain } \\
\text { Stimulation }\end{array}$ & $\begin{array}{l}\text { Cohadon } \\
\text { et al }\end{array}$ & 19 & Clinical study & 25 & $\begin{array}{l}\text { Post-traumatic } \\
\text { vegetative } \\
\text { state }\end{array}$ & $\begin{array}{l}\text { DBS treated group } \\
\text { only }\end{array}$ & $\begin{array}{l}\text { Changes in clinical } \\
\text { feathres and overall } \\
\text { behaviour }\end{array}$ & $\begin{array}{c}\text { Recovery of } \\
\text { some degree of } \\
\text { consciousness in } 13 \\
\text { cases. }\end{array}$ & 1 to 12 years \\
\hline $\begin{array}{l}\text { Deep Brain } \\
\text { Stimulation }\end{array}$ & $\begin{array}{l}\text { Katayama } \\
\text { et al }\end{array}$ & 20 & Case series & 8 & $\begin{array}{l}\text { Patients in } \\
\text { PVS }\end{array}$ & $\begin{array}{l}\text { DBS treated group } \\
\text { only }\end{array}$ & Pain-related P250 & $\begin{array}{l}\text { The Pain-related } \\
\text { P250 transiently } \\
\text { increased in } 4 \\
\text { patients. }\end{array}$ & $>6$ months \\
\hline $\begin{array}{l}\text { Deep Brain } \\
\text { Stimulation }\end{array}$ & $\begin{array}{c}\text { Yamamoto } \\
\text { et al }\end{array}$ & 21 & Case series & 21 & $\begin{array}{l}\text { Patients in } \\
\text { PVS }\end{array}$ & $\begin{array}{l}\text { DBS treated group } \\
\text { only }\end{array}$ & $\begin{array}{l}\text { Neurological and } \\
\text { electophysiological } \\
\text { evaluation }\end{array}$ & $\begin{array}{l}\text { Eight patients } \\
\text { emerged from PVS. }\end{array}$ & $>10$ years \\
\hline $\begin{array}{l}\text { Deep Brain } \\
\text { Stimulation }\end{array}$ & $\begin{array}{c}\text { Yamamoto } \\
\text { et al }\end{array}$ & 22 & Case series & 26 & $\begin{array}{l}\text { Patients in } \\
\text { PVS or MCS }\end{array}$ & $\begin{array}{l}\text { DBS treated group } \\
\text { only }\end{array}$ & $\begin{array}{l}\text { Neurological and } \\
\text { electophysiological } \\
\text { evaluation }\end{array}$ & $\begin{array}{l}\text { Eight patients } \\
\text { emerged from PVS, } \\
\text { and } 4 \text { from the } \\
\text { bedridden state. }\end{array}$ & $>10$ years \\
\hline $\begin{array}{l}\text { Deep Brain } \\
\text { Stimulation }\end{array}$ & $\begin{array}{c}\text { Yamamoto } \\
\text { et al }\end{array}$ & 23 & Case series & 107 & $\begin{array}{l}\text { Patients in } \\
\text { PVS }\end{array}$ & $\begin{array}{l}21 \text { DBS treated } \\
\text { vs } 86 \text { non-treated } \\
\text { group }\end{array}$ & $\begin{array}{c}\text { Auditory brainstem } \\
\text { response, somatosensory } \\
\text { evoked potential and pain- } \\
\text { related P250 }\end{array}$ & $\begin{array}{l}\text { Eight DBS-treated } \\
\text { patients emerged } \\
\text { from PVS and obey } \\
\text { verbal commands; } \\
\text { No patients with DBS } \\
\text { recovered. }\end{array}$ & $>10$ years \\
\hline $\begin{array}{l}\text { Deep Brain } \\
\text { Stimulation }\end{array}$ & Schiff et al & 24 & Case report & 1 & $\begin{array}{l}\text { Patients in } \\
\text { MCS }\end{array}$ & $\begin{array}{l}\text { DBS treated group } \\
\text { only }\end{array}$ & $\begin{array}{c}\text { Qualitative changes in } \\
\text { behaviour }\end{array}$ & $\begin{array}{c}\text { behavioural } \\
\text { improvements } \\
\text { (command following, } \\
\text { verbalization } \\
\text { and inconsistent } \\
\text { communication) }\end{array}$ & 6 months \\
\hline $\begin{array}{l}\text { Spinal Cord } \\
\text { Stimulatuin }\end{array}$ & Hosobuchi & 40 & Case series & 10 & $\begin{array}{l}\text { Stroke and } \\
\text { carotid } \\
\text { stenosis }\end{array}$ & $\begin{array}{l}5 \text { cervical SCS vs } 5 \\
\text { thoracic SCS }\end{array}$ & Cerebral blood flow & $\begin{array}{l}\text { Cervical SCS } \\
\text { significantly } \\
\text { increased CBF, } \\
\text { thoracic SCS had no } \\
\text { effect on CBF }\end{array}$ & N/A \\
\hline $\begin{array}{l}\text { Spinal Cord } \\
\text { Stimulatuin }\end{array}$ & $\begin{array}{c}\text { Yamamoto } \\
\text { et al }\end{array}$ & 43 & Case series & 10 & $\begin{array}{l}\text { Patients in } \\
\text { MCS }\end{array}$ & $\begin{array}{l}\text { SCS treated group } \\
\text { only }\end{array}$ & $\begin{array}{c}\text { electrophysiological } \\
\text { evaluations and SPECT }\end{array}$ & $\begin{array}{l}\text { Seven patients } \\
\text { recovered from } \\
\text { MCS following } \\
\text { SCS; Cervical SCS } \\
\text { increased CBF by } \\
22.2 \%\end{array}$ & $>1$ year \\
\hline $\begin{array}{l}\text { Spinal Cord } \\
\text { Stimulatuin }\end{array}$ & $\begin{array}{l}\text { Kanno } \\
\text { et al }\end{array}$ & 44 & $\begin{array}{l}\text { Prospective } \\
\text { uncontrolled } \\
\text { study }\end{array}$ & 214 & $\begin{array}{l}\text { Patients in } \\
\text { PVS }\end{array}$ & $\begin{array}{l}\text { SCS treated group } \\
\text { only }\end{array}$ & $\begin{array}{l}\text { Efficacy scale, detecting } \\
\text { signs of awareness of } \\
\text { self and surrounding and } \\
\text { SPECT }\end{array}$ & $\begin{array}{c}\text { Excellent and } \\
\text { positive results were } \\
\text { obtained in } 54 \% \text { of } \\
\text { patients }\end{array}$ & 3.5 months \\
\hline
\end{tabular}

Table 1: Clinical data of different studies. PVS, persistent vegetative state; MCS, minimally conscious state; DBS, deep brain stimulation; SCS, spinal cord stimulation; CBF, cerebral blood flow.

DBS to treat disorder of consciousness [18], and then in early 1990$\mathrm{s}$, two groups used this technique in a larger series of patients with vegetative state $[19,20]$.In one case-series study, DBS of the midbrain reticular formation or central thalamus was conducted in patients with MinCS 4- 8 months post-injury. They received continuous stimulation for 10 years. Eight of the 21 patients emerged from a vegetative state and were able to follow verbal instructions [21-23]. A case study observed improvements in the level of arousal, limb movement and verbalization after DBS to the central thalamus [24]. However, one has to be cautious to differentiate the effectiveness of DBS from spontaneous recovery following injury [25]. Sen et al also pointed out that differentiating between the PVS and MinCS may be important in determining the possible benefit of DBS therapy since either state may result from a traumatic brain injury and both have profound functional 
consequences [26]. It is not clear if PVS and MinCS respond differently to DBS. It is possible that patients with MinCS would respond better as areas of essential cortical functioning were relatively preserved $[24,26]$.

Furthermore, in one case report and one small case series study, DBS in the Ventralis Intermedius[VIM] nucleus of the thalamus, Ventralis Oral is Anterior and Posterior [VOA/VOP] and Globus Pallidus internus [GPi] has been used to treat posttraumatic tremor with good response $[27,28]$. A few small case series studies suggest that DBS of the Ventro Postero Lateral nucleus of the thalamus [VPL] and GPi can reduce symptoms of posttraumatic dystonia, which results in overall symptomatic improvement [29-31]. In addition, DBS of Subgenual Cingulate Cortex [SCC] is currently under investigation for the treatment of depression, a common neuropsychological disorder following TBI [7].

\section{Spinal Cord Stimulation}

Multiple animal studieshave shown augmentation of Cerebral Blood Flow [CBF] with Cervical Spinal Cord Stimulation[SCS][32-39]. The effect of SCS on increase in CBF in human brain was first reported in 1985 [40]. An interesting concept of "redistribution of CBF" rather than an absolute change in CBF during SCS was introduced in 1995 [41,42]. Further case series studies have shown cervical SCS could increase CBF, and improve upper-extremity motor function and communication skills in patients with MinCS resulted from TBI and stroke [7,43]. A singlegroup study reported improvements in awareness in 54\% [109/201] of people with stroke or TBI after cervical SCS [44]. The treatment effect may be achieved by enhancing cerebral hemodynamics via autonomic nervous system and the release of hormonal factors [45]. Moreover, based on the thorough literature review, it has been proposed that SCS targeting the lower cervical segments may prevent Subarachnoid Hemorrhage [SAH]-related delayed vasospasm [46-48]. Furthermore, once the vasospasm is present,patients may still receive additional benefit and possibly improve clinical outcome by CBF augmentation and treatment of thevasospasm through stimulation of the cervical spinal cord.

\section{Transcranial Magnetic Stimulation And Transcranial Direct-Current Stimulation}

Transcranial Magnetic Stimulation [TMS] and transcranial DirectCurrent Stimulation [tDCS] are two non-invasive neuromodulatory therapies, which can modulate neuroplasticity and cortical hyperexcitability[49-51].Their therapeutic value is unclear. Some studies, including randomized double-blind studyand sham stimulationcontrolled trial, have assessed their effects on motor function in people with stroke and TBI. The findings have been inconsistent [51-54].

\section{Neuromodulation for Spinal Cord Injury}

Traumatic Spinal Cord Injury[SCI] is estimated to affect approximately 300,000 individuals in the United States, and more than 2.5 million worldwide [55], with estimated cost over $\$ 9$ billion annually in the United States alone [56]. SCI often leads to serious neurological sequelae and medical complications. Therefore, more efforts in medical practice development are needed to improve the quality of life of patients with SCI.It has been reported that SCS in lumbosacral segments helped restore voluntary control of locomotion in paralyzed rats after SCI[57].A study using closed-loop neuromodulation to treat rats with complete SCI found that it improved the locomotion and enabled animals to perform more than 1,000 successive steps without failure and to climb staircases of various heights and lengths with precision and fluidity [58]. Another similar study on rats, however, found no treatment effect [59]. A case study reported that SCS enabled a paraplegic man [C7-T1 subluxation] to produce some leg movements and to stand during stimulation [60]. The author pointed out that even after a severe low cervical SCI, the neural networks remaining within the lumbosacral segments can be reactivated into functional states so that they can recognize specific details of ensembles of sensory input delivered by SCS to the extent that it [SCS] may serve as the source of neural control [60]. While this suggests that SCS can activate spared neural circuits and promote plasticity, there is no evidence that it would lead to functional gains and physical improvements after SCS.

\section{Neuromodulation for Epilepsy}

Epilepsy affects $1 \%$ of population in the world, and $30-40 \%$ of cases are medically refractory [61-65]. Management of patients who have recurrent seizures and did not respond to medication or surgery is challenging. A number of double-blind randomized controlled trials have confirmed the therapeutic effects of Vagus Nerve Stimulation [VNS] for epilepsy [66-69]. A recent European long-term study [ $n=347$ ] showed a $50 \%$ reduction in seizure frequency for up to $43.8 \%$ of patients[66]. Greater treatment effect has been observed with higher VNS settings [66]. A review study also found DBS effective in reducing seizure frequency [70]. The target areas of DBS for treatment of epilepsy include Anterior Nucleus [AN] of thalamus [71-73], centro median nucleus [CM] of thalamus [74,75], Sub Thalamic Nucleus [STN][76,77], Caudate Nucleus[75], cerebellum [78] and hippocampus [79]. Closed loop brain stimulation has recently been used for treatment of epilepsy. One type of this stimulation is a Responsive Neurostimulation System [RNS][Responsive Neurostimulation System, Neuropace, Mountain view, CA] that delivers stimuli only when abnormal electrocortico graphic activity of a seizure is detected [80]. Another type is a recording pulse generator unit [Medtronic, Minneapolis, MN][81] that deliver bidirectional stimulation. The RNS is approved by FDA for clinical use in the USA $[82,83]$, and the DBS - by the regulatory agencies in Canada, Europe, Australia, and elsewhere [61]. However,DBS is still in its early stage as a therapy for epilepsy.

\section{Discussion}

Overall, advances in neuromodulation may offer new therapeutic interventions for patients with stroke, traumatic brain injury, spinal cord injury and epilepsy by counteract the abnormal network in the brain. The emerging neuromodulation therapy for patients with these conditions is still facing great challenges. Since most of the existing findings are based on animal studies, preliminary data, case reports andpoor-controlled studies, and short follow up, further investigations including research and clinical trials are necessary to increase the applications of neurostimulation in the field of neurorehabilitation.

\section{References}

1. Morcom AM, Johnson W (2015)Neural reorganization and compensation in aging. J CognNeurosci 20:1-11

2. Depue BE, Orr JM, Smolker HR, Naaz F, Banich MT (2015)The Organization of right prefrontal networks reveals common mechanisms of inhibitory regulation across cognitive, emotional, and motor processes.Cereb Cortex 26:2424-2433

3. Ostergard T, Miller JP (2014)Deep brain stimulation: new directions. J NeurosurgSci 58:191-198

4. Okun MS (2014) Deep-brain stimulation-entering the era of human neuralnetwork modulation. N Engl J Med 15:1369-1373.

5. Leibson CL, Brown AW, Ransom JE, Diehl NN, Perkins PK, et al. (2011) Incidence of traumatic brain injury across the full disease spectrum: a population-based medical record review study. Epidemiology 22:836-844. 
Citation: Yin D, Slavin KV (2015) A Review of Neuromodulation in the Neurorehabilitation. Int J Neurorehabilitation 2: 151. doi:10.4172/23760281.1000151

6. Rothwell PM, Coull AJ, Silver LE et al.(2005) Population-based study of eventrate, incidence, case fatality, and mortality for all acute vascular events in all arterial territories (Oxford Vascular Study).Lancet 366:1773-1783.

7. Shin SS, Dixon E, Okonkwo DO, Richardson RM (2014) Neurostimulation for traumatic brain injury. J Neurosurg 121:1219-1231.

8. Kleim JA, Bruneau R, VandenBerg P, MacDonald E, Mulrooney R, et al. (2003) Motor cortex stimulation enhances motor recovery and reduces peri-infarct dysfunction following ischemic insult. NeurolRes 25:789-793.

9. Plautz EJ, Barbay S, Frost SB, Friel KM, Dancause N, et al.(2003) Post-infarc cortical plasticity and behavioral recovery using concurrent cortical stimulation and rehabilitative training: a feasibility study in primates. Neurol Res 25:801810

10. Teskey GC, Flynn C, Goertzen CD, Monfils MH, Young NA (2003) Cortical stimulation improves skilled forelimb use following a focal ischemic infarct in the rat. NeurolRes 25:794-800.

11. Yoon YS, Yu KP, Kim H, Kim HI, Kwak SH, et al. (2012) The effect of electric cortical stimulation after focal traumatic brain injury in rats. Ann RehabilMed 36:596-608.

12. Huang M, Harvey RL, Stoykov ME, Ruland S, Weinand M, et al. (2008) Cortical stimulation for upper limb recovery following ischemic stroke: a small phase II pilot study of a fully implanted stimulator. Top Stroke Rehabil 15:160-172.

13. Brown JA, Lutsep HL, Weinand M, Cramer SC (2006) Motor cortex stimulation for the enhancement of recovery from stroke: a prospective, multicenter safety study. Neurosurgery 58:464-473.

14. Levy R, Ruland S, Weinand M, Lowry D, Dafer R, et al. (2008) Cortical stimulation for the rehabilitation of patients with hemiparetic stroke: a multicenter feasibility study of safety and efficacy. J Neurosurg108:707-714.

15. Fontaine D, Hamani C, Lozano A (2009) Efficacy and safety of motor cortex stimulation for chronic neuropathic pain: critical review of the literature. Clinical article. J Neurosurg 110:251-256.

16. Zheng J, Liu L, Xue X, Li H, Wang S, et al.(2013) Cortical electrical stimulation promotes neuronal plasticity in the periischemic cortex and contralesional anterior horn of cervical spinal cord in a rat model of focal cerebral ischemia. Brain Res 1504:25-34.

17. Carmel JB, Kimura H, Berrol LJ, Martin JH (2013) Motor cortex electrical stimulation promotes axon outgrowth to brain stem and spinal targets that control the forelimb impaired by unilateral corticospinal injury. Eur $\mathrm{J}$ Neurosci37:1090-1102.

18. Hassler R, Ore GD, Dieckmann G, Bricolo A, Dolce G (1969) Behavioural and EEG arousal induced by stimulation of unspecific projection systems in a patient with post-traumatic apallic syndrome. ElectroencephalogrClinNeuroph ysiol 27:306-310

19. Cohadon F, Richer E (1993)Deep cerebral stimulation in patients with posttraumatic vegetative state. 25 cases. Neurochirurgie39:281-292.

20. Katayama Y, Tsubokawa T, Yamamoto T, Hirayama T, Miyazaki S, et al.(1991) Characterization and modification of brain activity with deep brain stimulation in patients in a persistent vegetative state: pain-related late positive component of cerebral evoked potential. Pacing ClinElectrophysiol 14:116-121.

21. Yamamoto T, Katayama $Y$ (2005)Deep brain stimulation therapy for the vegetative state. NeuropsycholRehabil. 15:406-413.

22. Yamamoto T, Kobayashi K, Kasai M, Oshima H, Fukaya C, et al.(2005) DBS therapy for the vegetative state and minimally conscious state. ActaNeurochirSuppl 93:101-104.

23. Yamamoto T, Katayama Y, Kobayashi K, Oshima H, Fukaya C, et al. (2010) Deep brain stimulation for the treatment of vegetative state. Eur $\mathrm{J}$ Neurosci 32:1145-1151.

24. Schiff ND, Giacino JT, Kalmar K, Victor JD, Baker K, et al.(2007) Behavioural improvements with thalamic stimulation after severe traumatic brain injury. Nature 448:600-603 (Erratum in Nature 2008, 452:120).

25. Schiff ND (2012) Moving toward a generalizable application of central thalamic deep brain stimulation for support of forebrain arousal regulation in the severely injured brain. Ann N Y AcadSci1265:56-68.

26. Sen AN, Campbell PG, Yadla S, Jallo J, Sharan AD (2010) Deep brain stimulation in the management of disorders of consciousness: a review of physiology, previous reports, and ethical considerations. Neurosurg Focus 29 (E14):1-6.
27. Foote KD, Seignourel P, Fernandez HH, Romrell J, Whidden E, et al. (2006) Dual electrode thalamic deep brain stimulation for the treatment of posttraumatic and multiple sclerosis tremor. Neurosurgery 58:280-286.

28. Lim DA, Khandhar SM, Heath S, Ostrem JL, Ringel N, et al. (2007) Multiple target deep brain stimulation for multiple sclerosis related and poststroke Holmes' tremor. StereotactFunctNeurosurg 85:144-149.

29. Carvalho KS, Sukul VV, Bookland MJ, Koch SA, Connolly PJ (2014) Deep brain stimulation of the globuspallidus suppresses post-traumatic dystonic tremor. J ClinNeurosci21:153-155

30. Loher TJ, Hasdemir MG, Burgunder JM, Krauss JK (2000) Long-term followup study of chronic globuspallidusinternus stimulation for posttraumatic hemidystonia. J Neurosurg 92:457-460.

31. Sellal F, Hirsch E, Barth P, Blond S, Marescaux C (1993) A case of symptomatic hemidystonia improved by ventroposterolateral thalamic electrostimulation. MovDisord8:515-518.

32. Ebel H, Schomäcker K, Balogh A, Volz M, Funke J, et al. (2001) High cervical spinal cord stimulation (CSCS) increases regional cerebral blood flow after induced subarachnoid haemorrhage in rats. Minim Invasive Neurosurg44:167-171.

33. Gurelik M, Kayabas M, Karadag O, Goksel HM, Akyuz A, et al. (1995) Cervica spinal cord stimulation improves neurological dysfunction induced by cerebral vasospasm. Neuroscience 134:827-832.

34. Isono M, Kaga A, Fujiki M, Mori T, Hori S (1995) Effect of spinal cord stimulation on cerebral blood flow in cats. StereotactFunctNeurosurg64:40-46.

35. Lee JY, Huang DL, Keep R, Sagher O (2008) Effect of electrical stimulation of the cervical spinal cord on blood flow following subarachnoid hemorrhage. $J$ Neurosurg109:1148-1154.

36. Patel S, Huang DL, Sagher O (2003) Sympathetic mechanisms in cerebral blood flow alterations induced by spinal cord stimulation. J Neurosurg99:754-761.

37. Patel S, Huang DL, Sagher O (2004) Evidence for a central pathway in the cerebrovascular effects of spinal cord stimulation. Neurosurgery 55:201-206.

38. Sagher O, Huang DL (2000) Effects of cervical spinal cord stimulation on cerebral blood flow in the rat. J Neurosurg93(Suppl. 1):71-76.

39. Yang X, Farber JP, Wu M, Foreman RD, Qin C (2008) Roles of dorsal column pathway and transient receptor potential vanilloid type 1 in augmentation of cerebral blood flow by upper cervical spinal cord stimulation in rats. Neuroscience 152:950-958.

40. Hosobuchi $Y$ (1985) Electrical stimulation of the cervical spinal cord increases cerebral blood flow in humans. AppINeurophysiol 48:372-376.

41. Mazzone P, Pisani R, Nobili F, Arrigo A, RosadiniG (1995)Assessment of regional cerebral blood flow during spinal cord stimulation in humans. StereotactFunctNeurosurg 64: 197-201.

42. Mazzone P, Rodriguez G,Arrigo A, Nobili F, Rosadini G (1996) Cerebra haemodynamic changes induced by spinal cord stimulation in man. Ital $\mathrm{J}$ NeurolSci 17: 55-57.

43. Yamamoto T, Katayama Y, Obuchi T, Kobayashi K, Oshima H, et al. (2012) Spinal cord stimulation for treatment of patients in the minimally conscious state. Neurol Med Chir (Tokyo) 52:475-481.

44. Kanno T, Morita I, Yamaguchi S, Yokoyama T, Kamei Y, et al. (2009) Dorsal column stimulation in persistent vegetative state. Neuromodulation. 12:33-38.

45. Visocchi M, Della Pepa GM, Esposito G, Tufo T, Zhang W, et al.(2011) Spinal cord stimulation and cerebral hemodynamics: Updated Mechanism and Therapeutic Implications. StereotactFunctNeurosurg89:263-274.

46. Goellner E, Slavin KV (2009) Cervical spinal cord stimulation may prevent cerebral vasospasm by modulating sympathetic activity of the superior cervical ganglion at lower cervical spinal level. Medical hypothesis 73:410-413.

47. Slavin KV, Vannemreddy PSSV, Goellner E, Alaraj AM, Aydin S, et al. (2011) Use of cervical spinal cord stimulation in treatment and prevention of arterial vasospasm after aneurismal subarachnoid hemorrhage: Technical detaiks. The Neuroradiology Journal 24:131-135.

48. Slavin KV (2014) Spinal stimulation for pain: Future applications. Neurotherapeutics 11:535-542.

49. Fregni F, Boggio PS, Valle AC, Rocha RR, Duarte J, et al. (2006) A sham- 
Citation: Yin D, Slavin KV (2015) A Review of Neuromodulation in the Neurorehabilitation. Int J Neurorehabilitation 2: 151. doi:10.4172/23760281.1000151

controlled trial of a 5-day course of repetitive transcranial magnetic stimulation of the unaffected hemisphere in stroke patients. Stroke 37:2115-2122.

50. Khedr EM, Ahmed MA, Fathy N, Rothwell JC (2005) Therapeutic trial of repetitive transcranial magnetic stimulation after acute ischemic stroke. Neurology 65:466-468.

51. Mansur CG, Fregni F, Boggio PS, Riberto M, Gallucci-Neto J, et al.(2005) A sham stimulation-controlled trial of rTMS of the unaffected hemisphere in stroke patients. Neurology 64:1802-1804.

52. Kim YH, You SH, Ko MH, Park JW, Lee KH, et al. (2006) Repetitive transcranial magnetic stimulation-induced corticomotor excitability and associated motor skill acquisition in chronic stroke. Stroke 37:1471-1476.

53. Takeuchi N, Tada T, Toshima M, Chuma T, Matsuo Y, et al. (2008) Inhibition of the unaffected motor cortex by $1 \mathrm{~Hz}$ repetitive transcranical magnetic stimulation enhances motor performance and training effect of the paretic hand in patients with chronic stroke. J RehabilMed 40:298-303.

54. Malcolm MP, Triggs WJ, Light KE, Gonzalez Rothi LJ, Wu S, et al. (2007) Repetitive transcranial magnetic stimulation as an adjunct to constraintinduced therapy: an exploratory randomized controlled trial. Am J Phys Med Rehabil86:707-715.

55. National Spinal Cord Injury Statistical Center (2013) Spinal cord injury facts and figures at a glance. J. Spinal Cord Med 36:1-2.

56. DeVivo MJ (2012) Epidemiology of traumatic spinal cord injury: trends and future implications. Spinal Cord 50:365-372.

57. Van Den Brand R, Heutschi J, Barraud Q, DiGiovanna J, Bartholdi K, et al (2012) Restoring voluntary control of locomotion after paralyzing spinal cord injury. Science 336:1182-1185.

58. Wenger N, Moraud EM, Raspopovic S, Bonizzato M, DiGiovanna J, et al. (2014) Closed-loop neuromodulation of spinal sensorimotor circuits controls refined locomotion after complete spinal cord injury. SciTransIMed 6:255ra133.

59. Lee CH, Hyun SJ, Yoon CY, Lim JY, Jahng TA, et al. (2012) Neuroprotective effects of sacral epidural neuromodulation following spinal cord injury: an experimental study in rats. J Korean NeurosurgSoc52:509-512.

60. Harkema S. Gerasimenko Y, Hodes J, Burdick J, Angeli C, et al. (2011) Effect of Epidural stimulation of the lumbosacral spinal cord on voluntary movement, standing, and assisted stepping after motor complete paraplegia: a case study. Lancet 377:1938-1947.

61. Laxpati NG, Kasoff WS, Gross RE (2014) Deep brain stimulation for the treatment of epilepsy: cirxuits, targets and trials. Neurotherapeutics 11:508526

\section{WHO. Epilepsy.}

63. Kwan P, Sperling MR (2009) Refractory seizures: Try additional antiepileptic drugs (after two have failed) or go directly to early surgery evaluation? Epilepsia50:57-62.

64. Wiebe S, Blume WT, Girvin JP, Eliasziw M. (2001) A randomized, controlled tria of surgery for temporal-lobe epilepsy. N Engl J Med 345:311-318.

65. Sander JW (2003) The epidemiology of epilepsy revisited CurrOpinNeurol16:165-170.

66. Orosz I, McCormick D, Zampono N, Varadkar S, Feucht M, et al. (2014) Vagus nerve stimulation for drug-resistant epilepsy: A European long-term study up to 24 months in 347 children. Epilepsia55:1576-1584.

67. A randomized controlled trial of chronic vagus nerve stimulation of medically intractable seizures. The Vagus Nerve Stimulation Study Group. Neurology 45:224-230.

68. Handforth A, DeGiorgio CM, Schachter SC, Uthman BM, Naritoku DK, et al. (1998) Vagus nerve stimulation therapy for partial-onset seizures: a randomized active-control trial. Neurology 51:48-55.

69. Klinkenberg S, Aalbers MW, Vles JS, Cornips EM, Rijkers K, et al. (2012) Vagus nerve stimulation in children with intractable epilepsy: a randomized controlled trial. Dev Med Child Neurol54:855-861.
70. Lega BC, Halpern CH, Jaggi JL, Baltuch GH (2010) Deep brain stimulation in the treatment of refractory epilepsy: update on current data and future directions. Neurobiol Dis 38: 354- 360 .

71. Andrade DM, Zumsteg D, Hamani C, Hodaie M, Sarkissian S, et al.(2006) Longterm follow-up of patients with thalamic deep brain stimulation for epilepsy. Neurology 66: 1571-1573.

72. Lee KJ, Shon YM, Cho CB (2012) Long-term outcome of anterior thalamic nucleus stimulation for intractable epilepsy. StereotactFunctNeurosurg 90: 379-385.

73. Fisher R, Salanova V, Witt T, Worth R, Henry T, et al. (2010) Electrical stimulation of the anterior nucleus of thalamus for treatment of refractory epilepsy. Epilepsia51: 899-908

74. Velasco AL, Velasco F, Jimenez F, Velasco M, Castro G, et al. (2006) Neuromodulation of the centromedian thalamic nuclei in the treatment of generalized seizures and the improvement of the quality of life in patients with Lennox- Gastaut syndrome. Epilepsia47: 1203-1212.

75. Chkhenkeli SA, Sramka M, Lortkipanidze GS, Rakviashvili TN, BregvadzeESh et al. (2004) Electrophysiological effects and clinical results of direct brain stimulation for intractable epilepsy. ClinNeurolNeurosurg106: 318-329.

76. Handforth A, DeSalles AA, Krahl SE (2006) Deep brain stimulation of the subthalamic nucleus as adjunct treatment for refractory epilepsy. Epilepsia47: 1239-1241.

77. Chabardes S, Kahane P, Minotti L, Koudsie A, Hirsch E, et al. (2002) Deep brain stimulation in epilepsy with particular reference to the subthalamic nucleus. Epileptic Disord 4: S83-S93.

78. Velasco F, Carrillo-Ruiz JD, Brito F, Velasco M, Velasco AL, et al.(2005) Doubleblind, randomized controlled pilot study of bilateral cerebellar stimulation for treatment of intractable motor seizures. Epilepsia46: 1071-1081.

79. Boon P, Vonck K, De Herdt V, Van Dycke A, Goethals M, et al. (2007) Deep brain stimulation in patients with refractory temporal lobe epilepsy. Epilepsia 48: $1551-1560$.

80. Morrell MJ (2011) RNS System in Epilepsy Study Group. Responsive cortica stimulation for the treatment of medically intractable partial epilepsy. Neurology 77: 1295-1304.

81. Stypulkowski PH, Stanslaski SR, Denison TJ, Giftakis JE (2013) Chronic evaluation of a clinical system for deep brain stimulation and recording of neural network activity. StereotactFunctNeurosurg91:220-232.

82. Bergey GK, Morrell MJ, Mozrahi EM, Goldman A, King-Stephens D, et al.(2015) Long-term treatment with responsive brain stimulation in adults with refractory partial seizures. Neurology 84: 810-817

83. Heck CN, King-Stephens D, Massey AD, Nair DR, Jobst BC, et al.(2014) Twoyear seizure reduction in adults with medically intractable partial onset epilepsy treated with responsive neurostimulation: final results of the RNS System Pivotal trial. Epilepsia55:432-441. 